\title{
MOUSE BLASTOCYSTS GROWN IN VIVO AND IN VITRO: CARBON DIOXIDE PRODUCTION AND TROPHOBLAST OUTGROWTH
}

\author{
TERESA M. MENKE* AND ANNE MaLAREN $\dagger$ \\ Department of Genetics, University of Edinburgh
}

(Received 6th October 1969)

Summary. (1) $\mathrm{CO}_{2}$ production by blastocysts cultured from the eight-cell stage in Brinster's medium was compared with that of uterine blastocysts recovered from females $3 \frac{1}{2}$ days p.c. The variation of $\mathrm{CO}_{2}$ output in different experiments was significantly greater for the cultured than for the control blastocysts; sometimes the $\mathrm{CO}_{2}$ output of cultured blastocysts was as high as that of the controls, but on average it was significantly lower.

(2) Adding foetal calf serum to the medium, or substituting glucose for lactate and pyruvate, did not increase the amount of $\mathrm{CO}_{2}$ produced by blastocysts cultured from the eight-cell stage, nor did it affect the proportion of eight-cell eggs developing to the blastocyst stage. Eagle's medium with foetal calf serum proved less successful than Brinster's medium in supporting development.

(3) Blastocysts which had developed from the eight-cell stage in culture, compared with control blastocysts recovered directly from the uterus and then cultured, showed a lower percentage attaching to the culture dish and a lower percentage with trophoblast outgrowth. All media tested permitted attachment, but only in those media containing serum did any appreciable number of embryos show trophoblast outgrowth.

(4) When blastocysts were cultured for $24 \mathrm{hr}$, the level of $\mathrm{CO}_{2}$ output of those taken from the uterus was not affected by the presence of serum in the culture medium; on the other hand, the blastocysts developed in vitro (which had a low initial $\mathrm{CO}_{2}$ output) showed a significantly higher level of $\mathrm{CO}_{2}$ production when serum was present. The association between $\mathrm{CO}_{2}$ output and trophoblast outgrowth suggests that metabolic activity needs to reach a certain level if trophoblast outgrowth in vitro, and implantation in vivo, are to occur.

\section{INTRODUGTION}

Potentially, the culture of pre-implantation mouse embryos (see Mintz, 1967, for a review of techniques) offers a valuable tool for the study of early development. In order to apply the results of experiments in vitro to the situation in vivo,

* Present address: Johns Hopkins University School of Medicine, Baltimore, U.S.A.

$\dagger$ Agricultural Research Council Unit of Animal Genetics. 
however, one must know how closely cultured embryos resemble normal embryos. Although the cultured blastocyst looks like the uterine blastocyst, there is evidence that normal morphology does not guarantee normal developmental potential on transfer, either to ectopic sites (Billington, Graham \& McLaren, 1968), or to the uterus of foster-mothers (Bowman \& McLaren, 1970). In the uterus, developmental failure of cultured blastocysts occurred both before and after implantation, and foetal weight was reduced.

An attempt was therefore made to achieve a direct comparison of the metabolic activities of cultured and uterine embryos. Critical metabolic developments occur between the eight-cell and the blastocyst stages. With the onset of cavitation, the rate of protein synthesis accelerates (Greenwald \& Everett, 1959; Weitlauf \& Greenwald, 1967) and protein content rises (Brinster, 1967b). The pattern of enzyme activity alters (Brinster, 1965b, 1966a, b) to favour respiration by way of the Embden-Meyerhof pathway and the tricarboxylic acid cycle. Studies on inhibitors of carbohydrate metabolism (Thomson, 1967) and of protein and nucleic acid synthesis (Thomson \& Biggers, 1966) have indicated that the embryo utilizes the same metabolic pathways in vitro as in vivo. The accelerated metabolic activity of the blastocyst in vivo is reflected in its oxygen consumption (Mills \& Brinster, 1967) and carbon dioxide output (Brinster, 1967a). In the present study, $\mathbf{C O}_{2}$ production was used to compare the metabolic activity of mouse blastocysts cultured from the eight-cell stage in a variety of media with that of blastocysts recovered from the uteri of female mice $3 \frac{1}{2}$ days post coitum (p.c.).

We have also compared the ability of trophoblast from cultured and uterine blastocysts to attach and show outgrowth in vitro. During cavitation, the embryo differentiates into two cell populations, the trophoblast and the inner cell mass, which are histochemically (Thomson \& Brinster, 1966; Mulnard, 1965) and functionally distinct. In vivo, the trophoblast invades the uterine epithelium after loss of the zona. In vitro, the fate of the trophoblast depends on the components of the medium in which it is suspended and on the surface available to it. Blastocysts cultured from the two-cell stage show trophoblast outgrowth on the walls of a millipore diffusion chamber in the peritoneal cavity (Bryson, 1964), on glass in a complex medium containing serum (Cole \& Paul, 1965), and on glass or plastic in Eagle's basal medium supplemented with foetal calf serum (Gwatkin, 1966a, b). Trophoblast outgrowth in vitro is considered to be analogous to trophoblast invasion in vivo (Bryson, 1964; Gwatkin, 1966a, b).

\section{MATERIAL AND METHODS}

\section{Culture of eight-cell embryos}

The oviducts of spontaneously ovulating, random-bred, $Q$ mice were flushed $2 \frac{1}{2}$ days p.c. with either phosphate-buffered saline or Brinster's medium containing lactate and pyruvate (Brinster, 1965a) and $3 \mathrm{mg} / \mathrm{ml}$ albumin (Bowman \& McLaren, 1970). The eight-cell embryos were transferred immediately to drops of medium under liquid paraffin (see Brinster, 1963) which had been equilibrated to $\mathrm{pH} 7 \cdot 2$. Table 1 describes the four media used in the study and 
lists the code names by which they will be designated in the remainder of this paper. B-1 and B-2 were made up in the laboratory once every 2 months and stored in 5-ml Bijou bottles at $-20^{\circ} \mathrm{G}$. Stock B-2 was prepared without an energy source; $1 \mathrm{mg} / \mathrm{ml}$ glucose was added before culture. B-1 plus serum was made up for each experiment by adding $1 \%$ foetal calf serum (Flow Laboratories) to stock B-1 solution. The media were filter-sterilized before use. Sterile

TABLE 1

A DESCRIPTION OF THE MEdiA USED IN STUDYING THE $\mathrm{CO}_{2}$ OUTPUT OF EMBRYOS GULTURED FROM THE EIGHT-CELL STAGE TO THE BLASTOGYST STAGE in vitro

\begin{tabular}{|c|c|c|c|c|}
\hline Code name & Reference & Energy source & $\begin{array}{l}\text { Albumin } \\
\text { content }\end{array}$ & $\begin{array}{l}\text { Serum } \\
\text { content }\end{array}$ \\
\hline B-1 & $\begin{array}{l}\text { Brinster (1965a) } \\
\text { modified by Bowman } \\
\text { \& McLaren (1970) }\end{array}$ & $\begin{array}{l}\text { Lactate and } \\
\text { pyruvate }\end{array}$ & $3 \mathrm{mg} / \mathrm{ml}$ & - \\
\hline B-1 + serum & $\begin{array}{l}\text { Brinster (1965a) } \\
\text { modified by Bowman } \\
\text { \& McLaren (1970) }\end{array}$ & $\begin{array}{l}\text { Lactate and } \\
\text { pyruvate }\end{array}$ & $3 \mathrm{mg} / \mathrm{ml}^{*}$ & $\begin{array}{l}1 \% \text { foetal } \\
\text { calf } \\
\text { serum }\end{array}$ \\
\hline B-2 & Brinster (1967a) & Glucose & $1 \mathrm{mg} / \mathrm{ml}$ & - \\
\hline Eagle's + serum & $\begin{array}{l}\text { Eagle (1955) } \\
\text { (Eagle's basal } \\
\text { medium) }\end{array}$ & & —* & $\begin{array}{l}1 \% \text { foetal } \\
\text { calf } \\
\text { serum }\end{array}$ \\
\hline
\end{tabular}

* The foetal calf serum in the medium presumably contained some albumin.

Eagle's basal medium was obtained from Flow Laboratories and stored at $4^{\circ} \mathrm{C}$. L-Glutamine and foetal calf serum to $1 \%$ were added on the day of culture.

The cultures were placed in an incubator maintained at approximately $36^{\circ} \mathrm{C}$ and gassed with a continuous flow of $10 \% \mathrm{CO}_{2}$ in air. After 40 to $44 \mathrm{hr}$, the cultures were examined and the percentage of embryos in the blastocyst stage was noted.

\section{Culture of blastocysts}

Uterine blastocysts were flushed from the uteri of $Q$ females $3 \frac{1}{2}$ days p.c. with stock B-2. Cultured blastocysts were taken directly from the microdrops in which they had developed from the eight-cell stage, and pooled in stock B-2.

The embryos were distributed to drops of B-1, B-1 plus serum, and Eagle's medium plus serum, under liquid paraffin in sterile disposable Escoplastic dishes (Esco Rubber Ltd). The blastocyst cultures were incubated under the same conditions as were the eight-cell cultures. Pre-attachment blastocysts destined for $\mathrm{CO}_{2}$ determinations were removed after $24 \mathrm{hr}$. The remaining embryos were examined daily for 4 days. On the 4th day, the percentage of blastocysts showing attachment and outgrowth was recorded and the extent of outgrowth noted. A blastocyst was considered to have attached when it could not be dislodged by vigorously shaking the culture dish. Outgrowth was assessed as described by Gwatkin (1966a, b). 


\section{Measurement of $\mathrm{CO}_{2}$ production}

Carbon dioxide output was measured by the liquid scintillation method of Brinster (1967a), in which the blastocyst metabolizes $\left[{ }^{14} \mathrm{C}\right]$ glucose to form ${ }^{14} \mathrm{CO}_{2}$, which is then trapped by hyamine hydroxide.

The embryos were washed three times in chemically-defined medium without energy source (Brinster, 1967a) and transferred in a minimal volume of fluid to $50 \mu \mathrm{l}$ of medium containing [ $\mathrm{U}_{-}{ }^{14} \mathrm{C}$ ] glucose $(1 \mathrm{mg} / \mathrm{ml})$ under $50 \mu \mathrm{l}$ of liquid paraffin in small glass or plastic test-tubes. The number of embryos in each determination was checked by observing the blastocysts in each tube under $\times 25$ magnification. The number of blastocysts per tube ranged from four to fifteen. At least two tubes with no embryos were included in each set of determinations in order to assess background radioactivity.

The tubes were placed in low-background liquid-scintillation vials along with empty decapitated 2-ml ampoules. The vials were sealed with rubber stoppers, gassed with $5 \% \mathrm{CO}_{2}$ in air, and incubated at $36^{\circ} \mathrm{C}$. After $4 \mathrm{hr}$, the embryos were killed and the $\mathrm{CO}_{2}$ liberated from the medium by injection of $0.1 \mathrm{ml}$ standard $\mathrm{M} / 20$-potassium hydrogen phthalate buffer $(\mathrm{pH} 4.0$ ) into the tubes through the rubber stoppers. Hyamine hydroxide $(1 \mathrm{ml})$ was similarly injected into the empty ampoules to absorb the ${ }^{14} \mathrm{CO}_{2}$. The stoppers were removed $24 \mathrm{hr}$ later, the test-tubes discarded, and $10 \mathrm{ml}$ of standard PPOPOPOP-toluene scintillation fluid mixed with the ${ }^{14} \mathrm{CO}_{2}$-labelled hyamine in the ampoules. The vials were stored overnight in the dark at $4^{\circ} \mathrm{C}$, which reduced background radioactivity from chemiluminescence and thermal noise to less than 30 counts/min. They were then counted for $30 \mathrm{~min}$ in a Packard Tri-Carb Liquid Scintillation spectograph, Model 3320, at a channel voltage optimal for the level of radioactivity of the ${ }^{14} \mathrm{CO}_{2}$.

The data in counts/min were converted to picomols of $\mathrm{CO}_{2} / \mathrm{embryo} / \mathrm{hr}$ as follows:

$$
P=\frac{k C}{E_{m} E_{h} n q t}
$$

where: $\mathbf{P}=$ picomols $\mathrm{CO}_{2} / \mathrm{embryo} / \mathrm{hr}$

$\mathbf{k}$ is the constant for converting picoCi to disintegrations/min and mols of glucose to mols of $\mathrm{CO}_{2} ; \mathrm{k}=3 /\left(1 \cdot 1 \times 10^{3}\right)$

$\mathrm{C}=$ sample counts $/ \mathrm{min}$ - background counts $/ \mathrm{min}$

$\mathrm{E}_{\mathrm{m}}=$ machine efficiency and quenching

$\mathrm{E}_{\mathbf{h}}=$ hyamine uptake efficiency

$\mathrm{n}=$ number of embryos in the sample

$\mathrm{q}=$ specific activity of $\left[{ }^{14} \mathrm{C}\right]$ glucose

$\mathrm{t}=$ incubation time

Machine efficiency and quenching were measured simultaneously using a known amount of benzoic $\left[{ }^{14} \mathrm{C}\right]$ acid external standard (5500 disintegrations/ $\mathrm{min} / \mathrm{mg}$, Packard) dissolved in $1 \mathrm{ml}$ hyamine plus $10 \mathrm{ml}$ scintillation fluid in the presence of a 2 -ml glass ampoule. The two factors cut the sensitivity to $63.9 \%$.

The efficiency with which hyamine trapped $\mathrm{CO}_{2}$ was assessed with a $\left[{ }^{14} \mathrm{C}\right]$ bicarbonate standard (specific activity $33 \mathrm{mCi} / \mathrm{mmol}$, Amersham). A carefully measured amount of radioactive bicarbonate in stock B-2 was added directly 
to hyamine. When glass tubes were used, the extraction efficiency was approximately $89 \%$; when plastic tubes were used, $98 \%$.

The specific activity of the $\left[\mathrm{U}-{ }^{14} \mathrm{C}\right]$ glucose (Amersham) ranged from 2.9 to $3 \cdot 1 \mathrm{mCi} / \mathrm{mmol}$.

Since the number of eggs/vial varied from four to fifteen, the estimated value for $\mathrm{CO}_{2} / \mathrm{egg} / \mathrm{hr}$ was weighted by the number of eggs in the vial before any statistical calculations were performed. All values for means, variances and other statistics are therefore weighted values. When differences between two values were to be combined, each difference was weighted by the factor $n_{1} n_{2} /$ $\left(n_{1}+n_{2}\right)$, where $n_{1}$ and $n_{2}$ were the numbers of eggs on which the two values were based. This procedure takes account of the fact that differences are more reliable when based on larger numbers of observations, and when the observations are more evenly distributed between the two groups.

To compare the $\mathrm{CO}_{2}$ outputs of individual cultured and uterine blastocysts more accurately, pairs of embryos were incubated in $20 \mu \mathrm{l}$ of high-radioactivity medium under $30 \mu \mathrm{l}$ of liquid paraffin. Previous studies indicated that reducing the volume of oil and medium did not alter blastocyst $\mathrm{CO}_{2}$ output. The highradioactivity medium contained approximately $0.1 \mathrm{mg} / \mathrm{ml}\left[\mathrm{U}-{ }^{14} \mathrm{C}\right]$ glucose (specific activity $320 \mathrm{mCi} / \mathrm{mmol}$, Amersham) plus $0.9 \mathrm{mg} / \mathrm{ml}$ carrier $\left[{ }^{12} \mathrm{C}\right]$ glucose. Several estimates of background were included in the experiment. Counts of more than 24 above the background level were considered to have come from ${ }^{14} \mathrm{CO}_{2}$ of blastocyst origin. Since the exact concentration of radioactive glucose in the culture medium was not measured, the uterine blastocysts were compared with the cultured blastocysts in terms of counts/min rather than $\mathrm{CO}_{2} / \mathrm{hr}$.

\section{RESULTS}

Carbon dioxide production of blastocysts developing from the eight-cell stage in vitro, in the B-1 medium, was compared on a number of occasions with that of control blastocysts recovered from the uteri of females $3 \frac{1}{2}$ days p.c. The results are given in Table 2.

The most striking feature of the data is the significantly higher level of variation between experiments in $\mathrm{CO}_{2}$ output of cultured as compared with control blastocysts (for Exps. 1 to $10, \mathrm{~F}=10 \cdot 0, P<0.01$ ). On some occasions, the cultured blastocysts produced significantly less $\mathrm{CO}_{2}$ than the controls; on others, there was no difference. In Experiment 12, which cannot be compared directly with the other experiments since a different source of radioactive glucose was used, the cultured and control groups were very similar, both in mean $\mathrm{CO}_{2}$ output and in variance. Evidently, the conditions of culture varied and were not always able to support metabolic activity at the level in vivo.

In an attempt to increase $\mathrm{CO}_{2}$ production of blastocysts cultured from the eight-cell stage, the medium was modified by adding $1 \%$ foetal calf serum (B-1 + serum), or by substituting glucose for lactate and pyruvate as an energy source (B-2). As can be seen from Table 3, both modifications depressed $\mathrm{CO}_{2}$ output, though not significantly.

The three media (B-1, B-1 + serum, B-2) proved equally successful in supporting development of eight-cell embryos to the blastocyst stage (Table 4). 
However, a significantly lower proportion of eight-cell embryos developed to the blastocyst stage in Eagle's basal medium supplemented with $1 \%$ foetal calf serum.

When blastocysts were recovered from the uterus and cultured in B-1, B-1+ serum or Eagle's medium + serum (Table 5), the majority became attached to

\section{TABLE 2}

THE EFFEGT OF GULTURE ON $\mathrm{CO}_{2}$ PRODUCTION BY MOUSE EMBRYOS MAINTAINED FOR 48 HR IN B-1 MEDIUM FROM THE EIGHT-CELL TO BLASTOCYST STAGE

\begin{tabular}{|c|c|c|c|c|c|c|c|c|}
\hline \multirow[b]{2}{*}{ Experiment } & \multicolumn{2}{|c|}{ No. of vials } & \multicolumn{2}{|c|}{ No. of blastocysts } & \multicolumn{3}{|c|}{ Mean $\mathrm{CO}_{2} /$ egg/hr (picomols) } & \multirow{2}{*}{$\mathrm{P}^{*}$} \\
\hline & Uterine & Cultured & Uterine & Cultured & Uterine & Cultured & Difference & \\
\hline 1 & 1 & 2 & 15 & 30 & $7 \cdot 55$ & $3 \cdot 91$ & $+3 \cdot 64$ & $<0.01$ \\
\hline 2 & 2 & 1 & 17 & 14 & 6.06 & $6 \cdot 32$ & -0.26 & $>0.2$ \\
\hline 3 & 1 & 1 & 8 & 5 & 8.07 & 11.52 & -3.45 & - \\
\hline 4 & 1 & 2 & 6 & 16 & 8.09 & 3.31 & +4.79 & $<0.10$ \\
\hline 5 & 2 & 1 & 10 & 12 & $7 \cdot 48$ & 7.57 & -0.09 & $>0.2$ \\
\hline 6 & 5 & 6 & 41 & 64 & $7 \cdot 55$ & $2 \cdot 37$ & $+5 \cdot 18 \pm 0 \cdot 51$ & $<0.001$ \\
\hline 7 & 1 & 2 & 7 & 19 & $6 \cdot 85$ & 5.05 & $+1 \overline{80}$ & $>0.2$ \\
\hline 8 & 1 & $\overline{1}$ & 6 & 8 & $7 \cdot 08$ & 3.04 & +4.04 & - \\
\hline 9 & 1 & $i$ & 6 & 6 & $9 \cdot 68$ & $9 \cdot 49$ & +0.19 & - \\
\hline 10 & 2 & 1 & 10 & 6 & 6.06 & 5.05 & +1.01 & $>0.2$ \\
\hline 12 & 14 & 12 & 28 & 24 & $29 \cdot 9 \dagger$ & $28 \cdot 2 \uparrow$ & $+1.7 \dagger$ & $>0.2$ \\
\hline
\end{tabular}

* Significance levels have been estimated where appropriate from the between- to withintreatment variance ratios.

$\dagger$ For Exp. 12, glucose of higher specific activity was used, and $\mathrm{CO}_{2}$ output is expressed in terms of mean counts/min minus background counts/min (see Methods section).

TABLE 3

THE EFFECT OF ADDING FOETAL CALF SERUM TO THE CONTROL B-1 MEDIUM, OR REPLACING LACTATE AND PYRUVATE BY GLUCOSE (B-2), ON $\mathrm{CO}_{2}$ PRODUCTION DURING CULTURE OF MOUSE EMBRYOS FOR 48 HR FROM THE EIGHT-GELL TO BLASTOCYST STAGE

\begin{tabular}{|c|c|c|c|c|c|c|c|c|c|}
\hline \multirow[b]{2}{*}{ Experiment } & \multicolumn{3}{|c|}{ No. of vials } & \multicolumn{3}{|c|}{ No. of blastocysts } & \multicolumn{3}{|c|}{ Mean $\mathrm{CO}_{2} / \mathrm{egg} / \mathrm{hr}$ (picomols) } \\
\hline & $B-1$ & $\begin{array}{c}B-1+ \\
\text { serum }\end{array}$ & $B-2$ & $B-1$ & $\begin{array}{c}B-1+ \\
\text { serum }\end{array}$ & $B-2$ & $B-1$ & $\begin{array}{l}B-1+ \\
\text { serum }\end{array}$ & $B-2$ \\
\hline $\begin{array}{l}2 \\
3 \\
4 \\
5\end{array}$ & $\begin{array}{l}1 \\
1 \\
2 \\
1\end{array}$ & $\begin{array}{l}2 \\
2 \\
2 \\
1\end{array}$ & $\begin{array}{r}1 \\
1 \\
-\end{array}$ & $\begin{array}{r}14 \\
5 \\
16 \\
12\end{array}$ & $\begin{array}{r}28 \\
18 \\
19 \\
9\end{array}$ & $\begin{array}{l}16 \\
11 \\
-\end{array}$ & $\begin{array}{r}6 \cdot 32 \\
11 \cdot 52 \\
3 \cdot 31 \\
7 \cdot 57\end{array}$ & $\begin{array}{l}6 \cdot 70 \\
4 \cdot 24 \\
2 \cdot 27 \\
6 \cdot 92\end{array}$ & $\begin{array}{c}4 \cdot 17 \\
10 \cdot 73 \\
- \\
-\end{array}$ \\
\hline Combined & 5 & 7 & 2 & 47 & 74 & 27 & $\begin{array}{r}7.18 \\
\pm 1.28\end{array}$ & $\begin{array}{l}5.03 * \\
\pm 0.72\end{array}$ & $\begin{array}{c}6 \cdot 84^{*} \\
\pm 3 \cdot 22\end{array}$ \\
\hline
\end{tabular}

* The depression of $\mathrm{CO}_{2}$ output is not statistically significant for either variant of the medium.

the surface of the Petri dish within $48 \mathrm{hr}$. Outgrowth of the trophoblast, on the other hand, was almost entirely restricted to blastocysts cultured in the two media containing serum. Blastocysts derived by culturing eight-cell embryos in B-1 were also transferred for $24 \mathrm{hr}$ to media containing serum. In Eagle's 
medium + serum, which was the only medium extensively tested, the blastocysts grown in culture showed a significantly lower percentage, both of attachment and of trophoblast outgrowth, than did uterine blastocysts $(P<0.01$ for each criterion).

We also examined the $\mathrm{CO}_{2}$ output of blastocysts maintained for $24 \mathrm{hr}$ either in B-1 alone, or in those media (B-1 + serum, Eagle's medium + serum) which

TABLE 4

THE EFFECT OF GULTURE MEDIUM ON THE PERCENTAGE OF EIGHT-CELL MOUSE EMBRYOS DEVELOPING TO THE BLASTOCYST STAGE

\begin{tabular}{|c|c|c|c|c|}
\hline & \multicolumn{4}{|c|}{ Culture medium } \\
\hline & $\begin{array}{c}B-1 \\
(\text { control })\end{array}$ & $\begin{array}{c} \\
\begin{array}{c}B-1 \\
+\end{array} \text { serum }\end{array}$ & $B-2$ & $\begin{array}{l}\text { Eagle's } \\
+ \text { +serum }\end{array}$ \\
\hline $\begin{array}{l}\text { No. of occasions } \\
\text { No. of eight-cell embryos cultured } \\
\% \text { blastocysts }\end{array}$ & $\begin{array}{r}20 \\
639 \\
77 \cdot 8\end{array}$ & $\begin{array}{r}6 \\
125 \\
80 \cdot 0\end{array}$ & $\begin{array}{r}5 \\
66 \\
80 \cdot 3\end{array}$ & $\begin{array}{c}3 \\
26 \\
23 \cdot 1 *\end{array}$ \\
\hline
\end{tabular}

$* P<0.001$ for comparison with control.

TABLE 5

THE EFFEGT OF GULTURE MEDIUM ON ATTACHMENT AND TROPHOBLAST OUTGROWTH OF MOUSE BLASTOCYSTS OBTAINED EITHER FROM THE UTERUS $3 \frac{1}{2}$ DAYS P.C., OR FROM GULTURE OF EIGHT-CELL EMBRYOS IN B-1

\begin{tabular}{|c|c|c|c|c|}
\hline \multirow[b]{2}{*}{$\begin{array}{l}\text { Origin of } \\
\text { blastocysts }\end{array}$} & \multirow[b]{2}{*}{$\begin{array}{l}\text { Behaviour of } \\
\text { blastocysts }\end{array}$} & \multicolumn{3}{|c|}{ Culture medium } \\
\hline & & $\begin{array}{c}B-1 \\
\text { (control) }\end{array}$ & $\begin{array}{l}B-1+ \\
\text { serum }\end{array}$ & $\begin{array}{c}\text { Eagle's }+ \\
\text { serum }\end{array}$ \\
\hline Uterus & $\begin{array}{l}\% \text { attaching } \\
\% \text { outgrowing }\end{array}$ & ${ }_{5 \cdot 6}^{72 \cdot 2}(18) \dagger$ & $\begin{array}{l}88 \cdot 5 \\
84 \cdot 6^{*}\end{array}$ & $\begin{array}{l}83 \cdot 2 \\
80 \cdot 6^{*}\end{array}$ \\
\hline $\begin{array}{l}\text { Culture } \\
\text { from } \\
\text { eight-cell }\end{array}$ & $\begin{array}{l}\% \text { attaching } \\
\% \text { outgrowing }\end{array}$ & $\overrightarrow{(0)}$ & $\begin{array}{l}100 \cdot 0 \\
50 \cdot 0^{(8)}\end{array}$ & $40 \cdot 6^{(64)}$ \\
\hline
\end{tabular}

$* P<0.001$ for comparison with control.

$\dagger$ Figures in parentheses indicate number of blastocysts.

were known to support trophoblast outgrowth. Both types of blastocyst were tested: those recovered directly from the uterus $3 \frac{1}{2}$ days p.c., and those derived from eight-cell embryos by culture for $48 \mathrm{hr}$ in B-1. The results are given in Table 6.

When blastocysts were taken directly from the uterus, $\mathrm{CO}_{2}$ output after culture for $24 \mathrm{hr}$ was slightly but not significantly lower with serum in the medium than with B-1 alone. By contrast, blastocysts which had developed from the eight-cell stage in culture showed a significantly higher $\mathrm{CO}_{2}$ output if transferred for a further $24 \mathrm{hr}$ to medium containing serum than if they were 
left in B-1. Eagle's medium + serum produced a greater effect than B-1 + serum, but not significantly so. The uterine and cultured blastocysts differed at the $1 \%$ level of significance in their response to serum.

TABLE 6

THE EFFECT OF 24-HR EXPOSURE TO SERUM AND $\mathrm{CO}_{2}$ PRODUCTION BY MOUSE BLASTOCYSTS OBTAINED EITHER FROM THE UTERUS OR FROM CULTURE OF EIGHT-CELL EMBRYOS

\begin{tabular}{|c|c|c|c|c|c|c|}
\hline $\begin{array}{l}\text { Origin of } \\
\text { blastocysts }\end{array}$ & $\operatorname{Exp}$. & $\begin{array}{c}\text { Mean } \\
\text { after a } \\
B-1 \\
\text { (control) }\end{array}$ & $\begin{array}{c}\mathrm{O}_{2} / \text { egg/hr } \\
\text { rther } 24-\mathrm{hr} \\
\mathrm{B}-1+ \\
\text { serum }\end{array}$ & $\begin{array}{l}\text { omols) } \\
\text { ture in: } \\
\quad \text { Eagle's } \\
\text { + serum }\end{array}$ & $\begin{array}{l}\text { Mean effect } \\
\text { of serum on } \\
\mathrm{CO}_{2} \text { output }\end{array}$ & Difference \\
\hline Uterus & $\begin{array}{l}10 \\
11\end{array}$ & $\begin{array}{l}6 \cdot 36(8)^{*} \\
8 \cdot 61(6)\end{array}$ & $\begin{array}{l}6 \cdot 15(8) \\
8 \cdot 00(7)\end{array}$ & $\begin{array}{l}4.41(10) \\
8 \cdot 50(7)\end{array}$ & $\begin{array}{c}-0.79 \\
\pm 0.45 \\
(P>0.2)\end{array}$ & \multirow{2}{*}{$\begin{array}{l}+2.56 \\
\quad \pm 0.67 \\
(P<0.01)\end{array}$} \\
\hline $\begin{array}{l}\text { Culture } \\
\text { from } \\
\text { eight-cell }\end{array}$ & $\begin{array}{l}10 \\
11\end{array}$ & $\begin{array}{l}4.51(11) \\
3.99(15)\end{array}$ & $\begin{array}{l}5 \cdot 33(12) \\
5 \cdot 37(13)\end{array}$ & $\begin{array}{l}6.38(11) \\
6.97(15)\end{array}$ & $\begin{array}{c}+1.77 \\
\quad \pm 0.50 \\
(P<0.05)\end{array}$ & \\
\hline
\end{tabular}

* Figures in parentheses denote the number of blastocysts tested; for the uterine blastocysts, one vial/treatment was used, and for the cultured blastocysts, two vials/ treatment.

\section{DISCUSSION}

Carbon dioxide production as an indication of the effect of culture

When cultured blastocysts which were morphologically normal were compared with uterine blastocysts in respect of their capacity to give rise to viable foetuses after transfer to foster mothers, all batches of cultured blastocysts proved inferior to the control blastocysts (Bowman \& McLaren, 1970). By contrast, our studies on $\mathrm{CO}_{2}$ production, carried out over the same period of time with medium from the same pool as that used by Bowman \& McLaren, detected some batches of cultured blastocysts which differed very little from uterine blastocysts, and others in which $\mathrm{CO}_{2}$ production was well below the control level. The mean level of the metabolic activity of the cultured blastocysts was significantly lower than that of the uterine blastocysts.

Thus, although $\mathrm{CO}_{2}$ output is a more sensitive tool than morphology for detecting the deleterious effect of culture, normal $\mathrm{CO}_{2}$ production at the blastocyst stage does not guarantee that subsequent development will be normal.

Effect of culture medium on $\mathrm{CO}_{2}$ output

Most of the embryos cultured from the eight-cell to the blastocyst stage in the present study were grown in a medium with a lactate-pyruvate energy source. By the eight-cell stage, the embryo is capable of metabolizing glucose (Whitten, 1956, 1957; Brinster \& Thomson, 1966). A small series of $\mathbf{C O}_{2}$ determinations with blastocysts cultured in a glucose medium indicated that 
substituting a six- for a three-carbon energy source at this stage does not influence metabolic activity. The study also showed that those embryos grown in the absence of glucose were at no disadvantage in the culture system used for $\mathrm{CO}_{2}$ determination, where the only available energy source was $\left[{ }^{14} \mathrm{C}\right]-$ glucose.

Of the three media most extensively used in studies of pre-implantation development (Mintz, 1964; Mulnard, 1965; Brinster, 1965a), two contain serum. In a preliminary experiment (unpublished), Bowman \& McLaren observed a higher mortality and lower foetal weight among embryos cavitating in vitro in the presence of $1 \%$ foetal calf serum and transferred to foster mothers, than among those cavitating in the absence of serum. In the present experiment, foetal calf serum did not enhance the development of eight-cell embryos. Neither the proportion of embryos reaching the blastocyst stage, nor the $\mathrm{CO}_{2}$ output of these blastocysts, was increased by including serum in the medium.

By contrast, blastocysts developed in vitro produced more $\mathrm{CO}_{2}$ after further culture for $24 \mathrm{hr}$ in medium containing serum than in medium not containing serum. Blastocysts developed in vivo, in which $\mathrm{CO}_{2}$ output was already relatively high, showed no further increase on culture in serum-supplemented medium.

The inability of cultured embryos to be stimulated by foetal calf serum until after cavitation is reminiscent of the inability of $2 \frac{1}{2}$-day embryos to implant in a $3 \frac{1}{2}$-day uterus (McLaren \& Michie, 1956; Noyes, Dickmann, Doyle \& Gates, 1963). The change in blastocyst metabolism which alters the response to serum must occur during cavitation in vitro.

\section{Carbon dioxide production, trophoblast outgrowth and implantation}

To bring about implantation, the mouse blastocyst interacts with the uterus in two apparently independent ways (McLaren, 1968a): (1) it sets off the decidual cell reaction by releasing its metabolic products in the vicinity of the uterine epithelium; (2) its trophoblast cells invade the uterine epithelium. The first signs of the decidual cell reaction and trophoblast invasion occur within a few hours of each other, both in normal implantation (Finn \& McLaren, 1967) and in delayed implantation (McLaren, 1968b).

The present study suggests that a certain threshold level of metabolic activity (of which $\mathrm{CO}_{2}$ production may be regarded as one index) is necessary, both for the induction of the decidual cell response and for trophoblast invasion. In a normal pregnancy, this threshold level of activation has probably been reached by the time cavitation is completed. At the blastocyst stage, exothermic metabolic pathways are opened, resulting in the output of markedly increased amounts of the by-products of metabolism, among them $\mathrm{CO}_{2}$ (Brinster, 1967a). A preliminary experiment (Menke \& McLaren, unpublished) has shown that in the $10 \mathrm{hr}$ before the onset of implantation, indicated by localized Pontamine Blue uptake, there is no further sharp rise in blastocyst metabolic activity. If the hormonal state of the uterus makes it receptive, the concentration of metabolic by-products in the vicinity of the embryo may be sufficient to induce the decidual cell reaction.

The outgrowth of trophoblast from blastocysts in vitro, which may be 
regarded as analogous to trophoblast invasion in utero (Bryson, 1964), occurs only under those conditions which we have found to favour metabolic activation, i.e. in medium supplemented with serum. Gwatkin (1966a) obtained outgrowth in Eagle's medium plus serum; we have found B-1 plus serum to be equally effective. B-1 alone neither stimulated $\mathrm{CO}_{2}$ output, nor supported outgrowth. Evidently some component in foetal calf serum induces trophoblast outgrowth and permits an increase in metabolic activity of cultured blastocysts to a level approaching that of uterine blastocysts. However, uterine blastocysts retained a high rate of $\mathrm{CO}_{2}$ production in B-1 yet showed no outgrowth, so metabolic activation is evidently not a sufficient condition for trophoblast outgrowth, though it may be a necessary one.

Our results differ from those of Gwatkin in that our blastocysts showed attachment (though not outgrowth) in B-1 alone. This may have been due to the higher concentration of albumin in our B-1, or to the fact that the blastocysts cavitated in vivo rather than in vitro. The lower percentage of attachment among our cultured blastocysts and the failure of some embryos to progress beyond the attachment phase under conditions optimal for outgrowth (Table 5) parallel the results of egg transfer studies (Bowman \& McLaren, 1970), in which cultured embryos suffered increased mortality both before and immediately after implantation.

Blastocysts in implantation delay, whether during lactation or after ovariectomy, resemble cultured blastocysts in that their $\mathrm{CO}_{2}$ output is generally lower than that of $3 \frac{1}{2}$-day uterine blastocysts in normal pregnancy (Menke \& McLaren, 1970). Blastocysts in delay lie within $1 \mu$ of the uterine epithelium without initiating the decidual cell response or invading the endometrium (McLaren, 1968b; Martin, Finn \& Carter, 1970). Gwatkin (1966b) observed that blastocysts prevented from implanting by ovariectomy early in pregnancy showed trophoblast outgrowth in culture only in medium supplemented by serum, i.e. where metabolic activation is likely to occur, and took longer to outgrow than did blastocysts cultured from the two-cell stage.

Metabolic activation of the blastocyst must be brought about by some factor(s) external to the embryo, since it does not occur in vitro in the absence of serum. The stimulus for activation in vivo presumably comes from the oestrogen-sensitized uterus. On the basis of his studies on blastocyst attachment and outgrowth, Gwatkin (1966b) suggested that implantation might be controlled by the free amino acid content of the uterine fluid.

\section{ACKNOWLEDGMENTS}

We wish to thank Dr John Bishop and his staff for technical advice and for the use of the liquid scintillation counter. One of us (T.M.) was supported by a grant from the U.S.-U.K. Educational Commission. The work was financed in part by the Ford Foundation.

\section{REFERENCES}

Billington, W. D., Graham, C. F. \& Mclaren, A. (1968) Extra-uterine development of mouse blastocysts cultured in vitro from early cleavage stages. F. Embryol. exp. Morph. 20, 391.

Bowman, P. \& McLaren, A. (1970) Viability and growth of mouse embryos after in vitro culture and fusion. F. Embryol. exp. Morph. 23, 693. 
BRINSTER, R. L. (1963) A method for in vitro cultivation of mouse ova from two-cell to blastocyst. Expl Cell Res. 32, 205.

Brinster, R. L. (1965a) Studies on the development of mouse embryos in vitro. IV. Interaction of energy sources. F. Reprod. Fert. 10, 227.

BRINSTER, R. L. (1965b) Lactate dehydrogenase activity in the preimplanted mouse embryo. Biochim. biophys. Acta, 110, 439.

BRINSTER, R. L. (1966a) Glucose 6-phosphate dehydrogenase activity in the preimplantation mouse embryo. Biochem. F. 101, 161.

BrInster, R. L. (1966b) Malic dehydrogenase activity in the preimplantation mouse embryo. Expl Cell Res. 43, 131.

BRINSTER, R. L. (1967a) Carbon dioxide production from glucose by the preimplantation mouse embryo. Expl Cell Res. 47, 271.

BRINSTER, R. L. (1967b) Protein content of the mouse embryo during the first five days of development. F. Reprod. Fert. 13, 413.

Brinster, R. L. \& Thomson, J. L. (1966) Development of eight-cell mouse embryos in vitro. Expl Cell Res. 42, 308.

BRYson, D. L. (1964) Development of mouse eggs in diffusion chambers. Science, N.Y. 144, 1351.

Cole, R. J. \& PAul, J. (1965) Properties of cultured preimplantation mouse and rabbit embryos, and cell strains derived from them. In: Preimplantation Stages of Pregnancy, pp. 82-112. Eds. G. E. W. Wolstenholme and M. O'Connor. Churchill, London.

EAGLE, H. (1955) Nutrition needs of mammalian cells in tissue culture. Science, N. Y. 122, 501.

FinN, C. A. \& McLaren, A. (1967) A study of the early stages of implantation in mice. $\mathcal{F}$. Reprod. Fert. $13,259$.

Greenwald, G. S. \& Everetr, N. B. (1959) The incorporation of $\mathbf{S}_{35}$ methionine by the uterus and ova of the mouse. Anat. Rec. 134, 171.

Gwatkin, R. B. L. (1966a) Defined media and development of mammalian eggs in vitro. Ann. N.Y. Acad. Sci. 139, 79.

Gwatkin, R. B. L. (1966b) Amino acid requirement for attachment and outgrowth of the mouse blastocyst in vitro. F. cell. comp. Physiol. 68, 335.

McLaren, A. (1968a) Stimulus and response during early pregnancy in the mouse. Nature, Lond. 221, 739.

MCLaren, A. (1968b) A study of blastocysts during delay and subsequent implantation in lactating mice. F. Endocr. 42, 453.

MaLaren, A. \& Michie, D. (1956) Studies on the transfer of fertilized mouse eggs to uterine fostermothers. 1. Factors affecting the implantation and survival of native and transferred eggs. F. exp. Biol. 33, 394.

Martin, L., Finn, C. A. \& Carter, J. (1970) The effects of progesterone and oestradiol-17 $\beta$ on the luminal epithelium of the mouse uterus. 7. Reprod. Fert. 21, 461.

Menke, T. M. \& MaLaren, A. (1970) Carbon dioxide production by mouse blastocysts during lactational delay of implantation or after ovariectomy. F. Endocr. 47, 284.

Mills, R. M. \& BRinster, R. L. (1967) Oxygen consumption of preimplantation mouse embryos. Expl Cell Res. 47, 337.

Mintz, B. (1964) Synthetic processes and early development in the mammalian egg. F. exp. Zool. 157, 85.

Mintz, B. (1967) Mammalian embryo culture. In: Methods in Developmental Biology, pp. 379-400. Eds. F. H. Wilt and N. K. Wessels. Crowell, New York.

Mulnard, J. G. (1965) Studies of regulation of mouse ova in vitro. In: Preimplantation Stages of Pregnancy, pp. 123-138. Eds. G. E. W. Wolstenholme and M. O'Connor. Churchill, London.

Noyes, R. W., Dickmann, Z., Doyle, L. L. \& Gates, A. H. (1963) Ovum transfers, synchronous and asynchronous, in the study of implantation. In: Delayed Implantation, pp. 197-209. Ed. A. G. Enders. University of Chicago Press.

Tномson, J. L. (1967) Effect of inhibitors of carbohydrate metabolism on the development of preimplantation mouse embryos. Expl Cell Res. 46, 252.

Thomson, J. L. \& Biggers, J. D. (1966) Effect of inhibitors of protein synthesis on the development of preimplantation mouse embryos. Expl Cell Res. 41, 411.

Thomson, J. L. \& Brinster, R. L. (1966) Glycogen content of preimplantation mouse embryos. Anat. Rec. 155, 97.

Weitlauf, H. M. \& Greenwald, G. W. (1967) A comparison of the in vivo incorporation of $\mathrm{S}_{35}$ methionine by two-celled mouse eggs and blastocysts. Anat. Rec. 159, 249.

Whitren, W. K. (1956) Culture of tubal mouse ova. Nature, Lond. 176, 96.

Whitten, W. K. (1957) Culture of tubal ova. Nature, Lond. 177, 1081. 